\title{
Failure of factor VIII inhibitor bypassing activity (Feiba) to secure haemostasis in haemophilic patients with antibodies
}

\author{
D. H. PARRY AND A. L. BLOOM
}

\begin{abstract}
From the Department of Haematology, Welsh National School of Medicine and University Hospital of Wales, Cardiff, UK
\end{abstract}

SUMMARY Factor IX concentrates have been widely advocated in the treatment of haemophilic patients with factor VIII inhibitors. Five such patients were given the 'activated' factor IX concentrate-factor VIII inhibitor bypassing activity (Feiba)-for 14 separate bleeding episodes. In six of the episodes, including two with external blood loss, bleeding progressed in spite of treatment. In none of the other eight episodes was there a prompt response, and it was not possible to ascribe a definite therapeutic effect.

A major complication of modern haemophilia therapy is the development of antibodies to factor VIII. This occurs in about $10 \%$ of treated patients, who become resistant to further treatment. Large doses of factor VIII may be effective in patients with low-titre inhibitors (Rizza and Biggs, 1973; Blatt et al., 1977), and plasmapheresis using a continuousflow cell separator has been employed to lower the inhibitor titre sufficiently to allow factor VIII replacement to be effective in others (Edson et al., 1973; Pintado et al., 1975). Another and controversial approach has been the use of 'factor IX' concentrates. These contain the vitamin $\mathrm{K}$ dependent factors II, VII, IX, and X as well as factor XI, but some lack factor VII, and all types may become 'activated' during preparation. Such 'active' concentrates fail their thrombogenicity tests and are not used for the treatment of Christmas disease. It has been claimed that these accidentally activated factor IX concentrates, for example, Autoproplex, Hyland (Fekete et al., 1972; Kurczynski and Penner, 1974), may contain a clotting factor intermediate which bypasses the site of action of factor VIII, and hence factor VIII antibodies, in the coagulation sequence and thus exerts a therapeutic effect in resistant haemophilic patients. Preparations purposely made to contain 'activated' factors have also been produced, for example, factor VIII inhibitor bypassing activity (Feiba, Immuno, Austria), and it has been claimed that these also exert a therapeutic effect even in the case of external bleeding (Preston

Received for publication 12 April 1978 et al., 1977). Recently, it has been claimed that nonactivated or 'routine' factor IX preparations (eg, Konyne, Cutter; Proplex, Hyland) may also be effective (Abildgaard et al., 1976; Kelly and Penner, 1976; Lowe et al., 1976). In contrast to these reports Pollock and Lewis (1976) found no benefit fromo using these products in one patient.

In this paper we report the unsuccessful use of the activated 'factor IX' preparation Feiba in a series of episodes of bleeding in haemophilic patients with factor VIII antibodies.

\section{Patients and methods}

All five patients were severe haemophiliacs (procoagulant factor VIII $0 \%$ ) who had developed factor VIII antibodies previously. Routine coagulation tests were performed using standard techniques (Biggs, 1976). Factor VIII inhibitor (antibody) assays were performed as described by Biggs and Bidwell (1959). Immunoradiometric assay (IRMA) of factor VIII related antigen was carried out as described by Peake and Bloom (1977).

\section{Results}

Fraction Feiba from seven different batches was used to treat 14 separate bleeding episodes. The clinical details are summarised in Table 1 . On six occasions therapy with Feiba was combined with factor VIII concentrate, as recommended by Schimpf et al. (1977), at a dosage of 32-114 units/kg. In six of the 14 episodes, including two with external blood 
Table 1 Use of fraction Feiba-summary of clinical results

\begin{tabular}{|c|c|c|c|c|c|c|c|}
\hline \multirow{2}{*}{\multicolumn{2}{|c|}{ Patient }} & \multirow[t]{2}{*}{ Lesion } & \multirow[t]{2}{*}{ Dose } & \multirow{2}{*}{$\begin{array}{l}\text { Additional } \\
\text { factor VIII }\end{array}$} & \multirow{2}{*}{$\begin{array}{l}\text { Clinical } \\
\text { response to } \\
\text { Feiba }\end{array}$} & \multicolumn{2}{|c|}{ Inhibitor titre $(u / m l)$} \\
\hline & & & & & & Pre & 2 weeks post \\
\hline \multirow[t]{6}{*}{$\mathbf{A}$} & 1 & Haemarthrosis elbow & $\begin{array}{l}96 \mathrm{u} / \mathrm{kg} \times 2 \\
20 \mathrm{u} / \mathrm{kg} 6 \text {-hrly } 2 \text { days }\end{array}$ & No & Slow & 32 & 24 \\
\hline & 2 & Haemarthrosis elbow & $\begin{array}{l}113 \mathrm{u} / \mathrm{kg} \times 1 \\
20 \mathrm{u} / \mathrm{kg} 6 \text {-hrly } 2 \text { days }\end{array}$ & Yes & Nil & 24 & - \\
\hline & 3 & $\begin{array}{l}\text { Traumatic haematomata } \\
\text { face, trunk* }\end{array}$ & $60 \mathrm{u} / \mathrm{kg} \times 2$ & Yes & Nil & 45 & 30000 \\
\hline & 4 & Haematoma of calf & 40-180 u/kg 6-hrly 2 days & Yes $\dagger$ & Nil & 1150 & 425 \\
\hline & 5 & Haemarthrosis elbow & $70 \mathrm{u} / \mathrm{kg} 12$-hrly 7 days & Yes $\dagger$ & Slow & 390 & - \\
\hline & 6 & Haemarthrosis wrist & $52-70 \mathrm{u} / \mathrm{kg} 12-8$-hrly 6 days & Yes $\dagger$ & Nil & 400 & - \\
\hline B & $\begin{array}{l}1 \\
2\end{array}$ & $\begin{array}{l}\text { Ilio-psoas haematoma } \\
\text { Haemarthrosis elbow }\end{array}$ & $\begin{array}{l}15 \mathrm{u} / \mathrm{kg} 8 \text {-hrly } 4 \text { days } \\
86 \mathrm{u} / \mathrm{kg} \times 1 \\
15 \mathrm{u} / \mathrm{kg} 6 \text {-hrly } 4 \text { days }\end{array}$ & $\begin{array}{l}\text { Yes } \\
\text { No }\end{array}$ & $\begin{array}{l}\text { Slow } \\
\text { Slow }\end{array}$ & $\begin{array}{l}8 \\
1 \cdot 1\end{array}$ & $\begin{array}{l}11 \\
0 \cdot 4\end{array}$ \\
\hline $\mathbf{C}$ & & Haemarthrosis knee & $\begin{array}{l}100 \mathrm{u} / \mathrm{kg} \times 1 \\
44 \mathrm{u} / \mathrm{kg} 6 \text {-hrly } 5 \text { days }\end{array}$ & No & Slow & 11 & 60 \\
\hline \multirow[t]{3}{*}{$\mathbf{D}$} & 1 & Haemarthrosis knee & $\begin{array}{l}100 \mathrm{u} / \mathrm{kg} \times 1 \\
30 \mathrm{u} / \mathrm{kg} 6 \text {-hrly } 2 \text { days }\end{array}$ & No & Slow & 7 & 8 \\
\hline & 2 & Haemarthrosis knee & $30 \mathrm{u} / \mathrm{kg}$ 6-hrly 2 days & Yes $\dagger$ & Slow & $3 \cdot 8$ & $2 \cdot 9$ \\
\hline & 3 & Haemarthrosis knee & $30-60 \mathrm{u} / \mathrm{kg} 8$-hrly 4 days & Yes & Nil & 2 & 10 \\
\hline \multirow[t]{2}{*}{$\mathbf{E}$} & 1 & Laceration ear lobe* & $128 \mathrm{u} / \mathrm{kg} 8$-hrly $\times 2$ & Yes $\dagger$ & Nil & 42 & 22 \\
\hline & 2 & Haematoma forearm & $110 \mathrm{u} / \mathrm{kg} \times 1$ & Yes $\dagger$ & Slow & 23 & 60 \\
\hline
\end{tabular}

*External bleeding

†Given concurrently with Feiba (15)

loss, the bleeding progressed in spite of therapy with Feiba, and additional treatment was necessary. In patient A, episode 3 , this consisted of plasmapheresis using an Aminco continuous-flow cell separator, which lowered the inhibitor titre from 45 to 7 units $/ \mathrm{ml}$ and enabled factor VIII concentrate to be used successfully in large doses: 374 units $/ \mathrm{kg}$ initially, then 189 units/kg every 12 hours for four days. In the other eight episodes none showed a prompt response to Feiba, and subsequent improvement was slow, often not beginning until a few days after the start of treatment. In these episodes it was not possible to be certain of a definite therapeutic effect of Feiba because slow resolution may have been due to bed rest alone.
The whole blood clotting time (WBCT), prothrombin time (PT), kaolin cephalin clotting time (KCCT), thrombin clotting time (TCT), and platelet count were performed before and after each infusion of Feiba. Factors II, V, VIII, and IX and fibrinogen assays were also performed. The results are summarised in Table 2. Only a minimal shortening of the PT and KCCT was seen on each occasion. The greatest effect was observed on the WBCT, as previously reported by Elsinger (1977). No evidence of disseminated intravascular coagulation was observed, and platelet counts, fibrinogen, and factor $\mathrm{V}$ levels remained unchanged.

For four of the bleeding episodes, no additional factor VIII was given, yet in one patient (C) there

Table 2 Feiba: Laboratory data-maximum change

\begin{tabular}{|c|c|c|c|c|c|c|c|c|c|}
\hline \multicolumn{2}{|c|}{ Patient } & \multicolumn{2}{|c|}{$P T(s)$} & \multicolumn{2}{|c|}{$K C C T(s)$} & \multicolumn{2}{|c|}{$W B C T(\min )$} & \multicolumn{2}{|c|}{$T C T(s)$} \\
\hline & & from & to & from & to & from & to & from & to \\
\hline \multirow[t]{6}{*}{$\mathbf{A}$} & 1 & 14 & 12 & 102 & 97 & 55 & 20 & 12 & 13 \\
\hline & 2 & 15 & 12 & 112 & 99 & - & - & 11 & 10 \\
\hline & 3 & 12 & 11 & 120 & 86 & 50 & 23 & 12 & 11 \\
\hline & 4 & 12 & 10 & 104 & 80 & 49 & 20 & 10 & 14 \\
\hline & 5 & 13 & 9 & 138 & 120 & 30 & 19 & $12 \cdot 5$ & 10 \\
\hline & 6 & 12 & 9 & 112 & 93 & 35 & 22 & 14 & 13 \\
\hline \multirow[t]{2}{*}{ B } & 1 & 15 & 14 & 118 & 114 & - & - & 14 & 13 \\
\hline & 2 & 14 & 11 & 132 & 128 & 55 & 35 & 15 & 13 \\
\hline \multirow{4}{*}{ D } & & 14 & 12 & 132 & 118 & - & - & 15 & 13 \\
\hline & 1 & 10 & 12 & 123 & 96 & 45 & 36 & 12 & 14 \\
\hline & 2 & 11 & 11 & 138 & 128 & 45 & 30 & 15 & 14 \\
\hline & 3 & 14 & 12 & 130 & 116 & 40 & 24 & 15 & 14 \\
\hline \multirow{2}{*}{$\mathbf{E}$} & 1 & 15 & 11 & 94 & 82 & 63 & 25 & 16 & 15 \\
\hline & 2 & 15 & 11 & 149 & 139 & 37 & 29 & 19 & 20 \\
\hline
\end{tabular}

No evidence of disseminated intravascular coagulation was observed in any treatment episode. 
was an associated secondary rise in the factor VIII inhibitor titre. This phenomenon has been previously reported (Allain and Krieger, 1975; Mannucci et al., 1976) and is probably due to small quantities of factor VIII present in the prothrombin complex concentrates. The batch of Feiba used for our patient was examined using a sensitive immunoradiometric assay for factor VIII related antigen (FVIIIRAg), and $0 \cdot 2-0 \cdot 3 \mathrm{u} / \mathrm{dl}$ was detected. In addition, greater or lesser amounts were found in several other factor IX concentrates (Table 3). Although FVIIIRAg is not the same antigen as that of procoagulant factor VIII the finding probably indicates contamination with the latter. In patients who received factor VIII concentrate, an anamnestic response was detected after three of the seven episodes (Table 1).

Table 3 Factor IX concentrates: FVIIIRAg by immunoradiometric assay

\begin{tabular}{llll}
\hline Concentrate & $\begin{array}{c}\text { FVIIIRAg } \\
\left(u / m l \times 10^{2}\right)\end{array}$ & Concentrate & $\begin{array}{l}\text { FVIIIRAg } \\
\left(u / m l \times 10^{2}\right)\end{array}$ \\
\hline 1 & 0.36 & 5 & 0.01 \\
& 0.42 & & 0.026 \\
1.47 & 6 & 0.056 \\
& 0.16 & & 0.23 \\
& 0.39 & 7 & \\
& 0.27 & & 0.35 \\
& 0.24 & & 0.34 \\
& 0.11 & 8 & 0.27 \\
& 14 & ('Activated') & 0.19 \\
2 & 6 & & 0.20 \\
& 3.2 & & \\
& 3.6 & & \\
3 & 2.7 & & \\
4 & 0.27 & & \\
\hline
\end{tabular}

\section{Discussion}

There are at least 18 reports claiming that factor IX concentrates of various types have secured haemostasis in haemophilic patients with inhibitors. In the present study, using the activated factor IX concentrate Feiba (Immuno), we have been impressed by the apparent lack of success of this form of treatment not only in closed bleeds, which are difficult to assess, but also in two patients with external bleeding even when used in high dosage and in combination with factor VIII concentrate (Schimpf et al., 1977; Brackmann et al., 1977). The reasons for the conflicting results are difficult to determine. As discussed by Blatt et al. (1977), assessment of closed bleeds is subjective, and bleeding may stop with rest and immobilisation. No controlled clinical trials have been reported, and the variable nature of the lesions, different levels and type of antibodies, and the small number of patients at each centre make these trials difficult to conduct. Doses have often been expressed as units of factor IX, but these are not necessarily related to the active agent or to the Feiba unit, and the factor IX assay itself could be affected by an activated clotting intermediate. The Feiba unit has been arbitrarily defined by the manufacturers (Elsinger, 1977) and, because it is related to the shortening of the clotting time of an antibody plasma, would be expected to be related more than the factor IX unit to a clinical effect. The methods of manufacture of most products, including Feiba, have not been released or may periodically change. The preparations may thus vary from product to product or even from batch to batch. Dosage schedules are therefore almost meaningless and entirely empirical. There is no reliable in-vitro method against which to assess a therapeutic effect although, as confirmed in the present study, there is usually moderate but incomplete correction of the whole blood clotting time (Elsinger, 1977). There is a recent report that the newer and possibly less thrombogenic factor IX preparations may be correspondingly less effective in factor VIII antibody patients (Kelly and Penner, 1976).

On the credit side, and as confirmed in the present study, untoward side-effects are few although there has been a report of disseminated intravascular coagulation (Stenbjerg and Jørgensen, 1977a), resistance to Feiba (Stenbjerg and Jørgensen, 1977b), and one disturbing case of transient amaurosis (Rasches et al., 1977). Anamnestic response of factor VIII antibody is less likely to occur than with factor VIII concentrate, and the treatment is certainly much less expensive. Recently, Brackmann et al. (1977) and Schimpf et al. (1977) have claimed that a combination of high doses of factor VIII and factor IX concentrates may be effective and that sustained use may even lead to the disappearance of the factor VIII antibodies, but this claim has yet to be substantiated. The high cost, for example $£ 1000$ a day for many months in one patient (Brackmann and Gormsen, 1977), and the redistribution of blood products involved are undesirable aspects of this treatment programme.

The initial enthusiastic reports of the use of these activated factor IX preparations for the treatment of haemophilic patients with antibodies have led to their widespread uncontrolled use and the publication of several confirmatory reports. Our experience suggests that this impression may have been over optimistic, and there is no doubt that Feiba is not as effective as are factor VIII concentrates in normally responsive haemophiliacs. There is an urgent need for more controlled investigations of the manufacture and clinical effects of the materials, which will probably need to be assessed on a multicentre basis. If one of them is really effective then characterisa- 
tion and isolation of the active principle could help to solve this important clinical problem.

We thank Mr N. Berry of Immuno (UK) for supplies of Feiba, Dr E. Bidwell for Oxford DE (1) concentrate, and Dr D. S. Pepper for samples of other factor IX concentrates. We thank Dr I. R. Peake for results of FVIIIRAg assays and Dr J. C. Giddings and his colleagues for performing numerous coagulation studies and factor VIII and inhibitor assays.

\section{References}

Abildgaard, C. F., Britton, M., and Harrison, J. (1976). Prothrombin complex concentrates (Konyne) in the treatment of hemophilic patients with factor VIII inhibitors. Journal of Pediatrics, 88, 200-205.

Allain, J. P., and Krieger, G. R. (1975). Prothrombincomplex concentrate in treatment of classical haemophilia with factor-VIII antibody (Letter). Lancet, 2, 1203.

Biggs, R. (1976). Human Blood Coagulation, Haemostasis and Thrombosis, 2nd edition. Blackwell, Oxford.

Biggs, R., and Bidwell, E. (1959). A method for the study of antihaemophilic globulin inhibitors with reference to six cases. British Journal of Haematology, 5, 379-395.

Blatt, P. M., White, G. C., II, McMillan, C. W., and Roberts, H. R. (1977). Treatment of anti-factor VIII antibodies. Thrombosis and Haemostasis, 38, 514-523.

Brackmann, H. H., Etzel, F., Hofmann, P., and Egli, H. (1977). The successful treatment of acquired inhibitors against factor VIII (Abstra:t). Thrombosis and Haemostasis, 38, 369.

Brackmann, H. H., and Gormsen, J. (1977). Massive factor-VIII infusion in a haemophiliac with factorVIII inhibitor, high responder (Letter). Lancet, 2, 933.

Edson, J. R., McArthur, J. R., Branda, R. F., McCullough, J. J., and Chou, S. N. (1973). Successful management of a subdural hematoma in a hemophiliac with an anti-factor VIII antibody. Blood, 41, 113-122.

Elsinger, F. (1977). Preparations with factor VIII inhibitor bypassing activity. Workshop on Inhibitors of Factors VIII and IX, p. 101. Facultas-Verlag, Vienna.

Fekete, L. F., Holst, S. L., Peetom, F., and Deveber, L. L. (1972). 'Auto'-factor IX concentrate: a new therapeutic approach to treatment of hemophilia A patients with inhibitors. 14th International Congress of Hematology, São Paulo, Brazil, Abstracts, No. 295.

Kelly, P., and Penner, J. A. (1976). Antihemophilic factor inhibitors: management with prothrombin complex concentrates. Journal of the American Medical Association, 236, 2061-2064.

Kurczynski, E., and Penner, J. A. (1974). Activated prothrombin concentrate for patients with factor VIII inhibitors. New England Journal of Medicine, 291, 164-167.

Lowe, G. D. O., Harvie, A., Forbes, C. D., and Prentice, C. R. M. (1976). Successful treatment with prothrombin complex concentrate of post-operative bleeding in a haemophiliac with a factor VIII inhibitor. British Medical Journal, 2, 1110-1111.

Mannucci, P. M., Bader, R., and Ruggeri, Z. M. (1976). Concentrates of clotting-factor IX (Letter). Lancet, 1 , 41.

Peake, I. R., and Bloom, A. L. (1977). The use of an immunoradiometric assay for factor VIII related antigen in the study of atypical von Willebrand's disease. Thrombosis Research, 10, 27-32.

Pintado, T., Taswell, H. F., and Bowie, E. J. W. (1975). Treatment of life-threatening haemorrhage due to acquired factor VIII inhibitor. Blood, 46, 535-541.

Pollock, A., and Lewis, M. J. (1976). Factor-VIII inhibitor bypassing activity (Letter). Lancet, 2, 43-44.

Preston, F. E., Dinsdale, R. C. W., Sutcliffe, D. J., Bardhan, G., Wyld, P. J., and Hamlyn, J. F. (1977). Factor VIII inhibitor bypassing activity (FEIBA) in the management of patients with factor VIII inhibitors. Thrombosis Research 11, 643-651.

Rasche, H., Bindewald, H., Köhle, W., Scheck, R., Heinrich, R., and Seibert, K. (1977). Notfallbehandlung von Blutungskomplikationen bei HemmkörperHämophilie mit aktivierten Prothrombinkomplexkonzentraten. Deutsche mediznische Wochenschrift, 102, 319-323.

Rizza, C. R., and Biggs, R. (1973). The treatment of patients who have factor-VIII antibodies. British Journal of Haematology, 24, 65-82.

Schimpf, K., Zimmermann, K., and Zeltsch, P. (1977). Treatment of joint-bleedings in hemophiliacs with antibodies to factor VIII with high doses of fraction FEIBA (Abstract). Thrombosis and Haemostasis, 38, 369.

Stenbjerg, S., and Jørgensen, J. (1977a). Disseminated intravascular coagulation and infusion of factor-VIIIinhibitor bypassing activity (Letter). Lancet, 1, 360 .

Stenbjerg, S., and Jørgensen, J. (1977b). Resistance to activated F IX concentrate (FEIBA). Scandinavian Journal of Haematology, 18, 421-426.

Requests for reprints to: Professor A. L. Bloom, Department of Haematology, University Hospital of Wales, Heath Park, Cardiff, CF4 4XN, UK 